\title{
Simultaneous determination of dissolved organic carbon and total dissolved nitrogen in seawater by high temperature catalytic oxidation: conditions for precise shipboard measurements
}

\author{
Xosé A. Álvarez-Salgado ${ }^{\mathrm{a}, \mathrm{b}}$, Axel E.J. Miller ${ }^{\mathrm{b}}$ \\ ${ }^{a}$ C.S.I.C., Instituto de Investigacións Mariñas, Eduardo Cabello 6, Vigo, E-36208, Spain \\ ${ }^{\mathrm{b}}$ N.E.R.C., Plymouth Marine Laboratory, Prospect Place, Plymouth, PL1 3DH, UK
}

\begin{abstract}
Appropriate conditions have been achieve $d$ for the accurate, rapid, and highly precise shipboard simultaneous determination of dissolved organic carbon and total dissolved nitrogen in seawater by high tem perature catalytic oxidation. A nitrogen-specific Antek 705D chemiluminescence detector and a $\mathrm{CO}_{2}$-specific LiCor Li6252 IRGA have been coupled inseries with a Shimadzu TOC-5000 organic carbon analy ser. Precision of both sim ultaneous measurements is $\leq 1.5 \%$, i.e., $\pm 1 \mu \mathrm{mol} \mathrm{C} 1^{-1}$ and $\pm 0.3 \mu \mathrm{mol} \mathrm{N} 1^{-1}$, respectively. Quality of analysis is not compromised by vibrations associated with ocean going research vessels.
\end{abstract}

Key words: HTCO, DOC, DON, simultaneous measurement

\section{Introduction}

Despite a retraction of the original pa pers (Suzuki, 1993), the works by Suzuki et al. (1985) and Sugimura and Suzuki (1988) initiated a debate which has clearly contributed to improve the determination of DOC and DON by high temperature catalytic oxidation (HTCO). During the 1991 Seattle DOC/DON Workshop (Hedges and Lee, 1993), HTCO was recognised as the most precise and efficient technique for the oxidation of dissolved organics in seawater (Hedges, 1993). Subsequently, marine chemists have been largely concerned with the determination of DOC by HTCO (Sharp et al., 1993; Cauwet, 1994; Sharp et al., 1995, etc.), but little attention has been paid to the determination of DON (Hansell et al., 1993; Cifuentes et al., 
1994). The aim of this work was to determ ine and optimise conditions for the rapid and precise shipboard simultaneous determination of DOC and DON by HTCO.

HTCO techniques ty pically involve the direct injection of filtered, acidified and decarbonated seawater onto a Pt-coated catalyst at high temperature $\left(\geq 600^{\circ} \mathrm{C}\right)$ in an atmosphere of high purity air or oxygen (Williams, 1992; Perdue et al., 1993; Cauwet, 1994). Quantitative production of $\mathrm{CO}_{2}$ and $\mathrm{NO} \bullet$ gases occurs under these conditions. DOC concentration is directly related to the am ount of $\mathrm{CO}_{2}$ produced, which is determ ined by infrared gas analy sis. Total dissolved nitrogen is determ ined by a nitrogen-specific chemiluminescence reaction: DON can be obtained by subtracting the independently measured dissolved inorganic nitrogen to the HTCO-TDN. A problem with the precision of DON measurements remains in deep waters, where the DON contribution to the TDN signal is small, $<10 \%$ (Hansell, 1993).

\section{Methods}

HTCO measurements were performed using a com mercial Shimadzu TOC-5000 analyser (Shimadzu, Kyoto, Japan) coupled to an Antek 705D nitrogen-specific chemiluminescence detector (Antek Instruments Inc., Texas, USA ). Incorporation of a LiCor Li6252, solid-state infrared gas analy zer (IRGA; LiCor, Nebraska, USA), in conjunction with a PC-based integration software package (Ati Unicam 4880; Cam bridge, UK) allows high precision measurements to be $\mathrm{m}$ ade against a background signal distortion caused by the vibrations usually found on a research ship (Pe ltzer and Brewer, 1993; Sharp et al., 1993). The Shimadzu-IRGA, with a membrane-based pressure differential detection mechanism, is prone to interference from both low (ship's roll) a nd high frequency vibrations. The LiCor Li6252 incorporates a lead selenide solid state photometric detection device that is insensitive to such movements (Peltzer and Brewer, 1993).

The pre-treated sample is injected (200 $\mu 1)$ into the Shimadzu TOC-5000 furnace, filled with a pre-conditioned Shim adzu catalyst $\left(\mathrm{Al}_{2} \mathrm{O}_{3}\right.$ impregnated with $0.5 \%$ platinum), at $680{ }^{\circ} \mathrm{C}$ (Fig. 1a). The com bustion products $\left(\mathrm{CO}_{2}, \mathrm{NO} \bullet, \mathrm{H}_{2} \mathrm{O}\right.$, etc.) are carried by high purity oxygen (99.999\%; Linde Gas UK Ltd., Manchester, UK) through a 25\% $\quad \mathrm{H}_{3} \mathrm{PO}_{4}$ solution (IC reaction 
vessel) to prevent dissolution of $\mathrm{CO}_{2}$ into water vapour. Then, the stream passes through an inbuilt Peltier cooler at $\sim 1^{\circ} \mathrm{C}$ (electronic dehumidifier) for removal of water vapour, and finally through a Shimadzu halogen scrubber. After passi ng through a Shimadzu particle filter $(20 \mathrm{~mm}$ $\varnothing$, sub-micron membrane), the dried gas mixture enters the measuring cell of the LiCor Li6252, and then, in series, enters the m easuring cell of the Shim adzu IRGA (which is necessary to control the automatic injection system of the Shimadzu TOC-5000).

The combustion gases are routed to the Antek 705D detector, by pulling with a Vacuubrand MZ 2D diaphragm vacuum pump (ABM, Germany) at the exit of an Antek permeation-tube drier (see below) to lower the pressure within the $\mathrm{NO}_{\mathrm{x}} / \mathrm{O}_{3}$ reaction cham ber (Fig. 1b). This minimises background luminescence and increases sensitivity (Walsh, 1989). A high precision controller (Orm e Scientific Ltd., Ma nchester, UK) is used to keep a constant vacuum of -25 " $\mathrm{Hg}(-635 \mathrm{~m} \mathrm{mHg})$; this is critical to maintain the constant flow through the reaction cell which is necessary to perform precise measurements. To keep the vacuum from drawing water through the Shim adzu TOC-5000, a T-piece has been installed after the Shimadzu IRGA. The flow through the Antek 705D is set to $\sim 75 \%$ of the total flow $(=150 \mathrm{~m} 1$ $\min ^{-1}$ ) by means of an extra-fine Nupro (Swagelock) m etering valve (Bristol Valve and Fitting Co., Bristol, UK). The rem aining $25 \%\left(=37.5 \mathrm{~m}^{-1} \mathrm{~min}^{-1}\right)$ is vented to the atm osphere. This configuration avoids all backpressure problems derived from running both sy stems in-line. Moisture not rem oved by the Shim adzu dehumidifier could exert significant influence on nitrogen recovery and, in addition, it quenches the chemiluminescence reaction, causing peak tailing (Walsh, 1989). This prom pted the installation of a $28 \mathrm{ml}$ (140 $\mathrm{mm}$ x $8 \mathrm{~mm}$ i.d.) Drierite trap (97\% $\mathrm{CaSO}_{4}, 3 \% \mathrm{CoCl}_{3} ; 10 / 20$ mesh; NBS Biologicals Ltd., Huntingdon, UK) after the Tpiece, to visually check the presence of $\mathrm{H}_{2} \mathrm{O}$ in the sy stem. Replenisment of wet Drierite is simple and rapid. As a precautionary measure, the Antek $\mathrm{m}$ embrane drier was installed downstream. The dried $\mathrm{NO} \bullet$ is then $\mathrm{m}$ ixed with $\mathrm{O}_{3}$, leading to production of the excited chemiluminescent $\mathrm{NO}_{2}$ species, which emits quantifiable light energy upon decay to its ground state. Oxygen flow through the ozone generator is set to $\sim 50 \mathrm{~m}^{1 \mathrm{~min}^{-1}}$ (1.5 units in the Antek 
705D front panel flowm eter), at 0.5 bar pressure. Such low oxy gen inflow increases residence time of oxy gen in the ozone generator. This enriches the outflow, and enhances the baseline stability. For the TDN levels usually found in seawater $\left(5-50 \mu \mathrm{m} \mathrm{ol} \mathrm{N} 1^{-1}\right)$, the Antek 705D photomultiplier (PMT) voltage must be set to $800 \mathrm{~m} \mathrm{~V}$, in the range of $\mathrm{x} 10$. An injection cycle takes $5 \frac{1}{2} \mathrm{~m}$ inutes: as each sam ple is injected 3-4 tim es, $\sim 17-22 \mathrm{~min}$ are necessary for completion.

\section{Results and discussion}

\subsection{Standardisation and blanks. Consistency of HTCO-DOC and TDN measurements}

Peaks obtained with the Li6252 (Fig 2a) correspond to a 5-point calibration curve in the range 0-200 $\mu \mathrm{mol} \mathrm{l}^{-1}$ spiked-C, using a mixed standard of potassium hydrogen phthalate (KHP) and glycine in Milli-Q water. Peaks sim ultaneously obtained with the Antek 705D detector for the same mixed standard (range $0-25 \mu \mathrm{mol} \mathrm{l}^{-1}$ spiked-N) are also shown (Fig. 2b). The CV for the 3-4 replicate analy ses of each spiked solution are typically $<1.5 \%$ for both DOC and TDN measurements, even for the lowest standard: $50 \mu \mathrm{mol}^{-1}$ spiked-C and $6.4 \mu \mathrm{mol} \mathrm{l}^{-1}$ spiked-N. So, the system is sufficiently sensitive to accurately detect the lowest DOC and TDN concentrations in natural seawater: $\sim 40 \mu \mathrm{mol} \mathrm{C} 1^{-1}$ and $5 \mu \mathrm{mol} \mathrm{N}^{-1}$. The CV for replicate analy sis of Milli-Q water was obviously much larger and the measured concentrations range from 2 to $5 \mu \mathrm{mol} \mathrm{C} \mathrm{^{-1 }}$ and 0.3 to $0.7 \mu \mathrm{mol} \mathrm{N}^{-1}$ from day to day. The sy stem is calibrated on a peak area basis. A collection of five calibration curves, obtained at $\sim 24 \mathrm{hr}$ intervals during routine analy sis of natural seawater samples in the laboratory, are shown in Figure 2c. The CVs of the five corresponding slopes were $<1 \%$ for both DOC and TDN, indicating $\mathrm{m}$ inimal variation in recovery efficiencies from day to day; even though salt was progressively accumulating within the column. Our results contrast with the $>10 \%$ increase during a two week period observed by Tanoue (1993).

Low and stable 'systems blanks' are obtained when the catalyst is properly conditioned. Conditioning consists of running the 'blank check' programme of the Shim adzu TOC-5000 several times, to wash the cataly st with a large volum e of Milli-Q water (Suzuki et al., 1992; 
Benner and Storm, 1993; Cauwet, 1994; Laodong and Santschi, 1997). Injection of py rolised water from the pyrowater trap (Fig. 1a) serves to obtain the 'sy stem blank', assuming that this water is carbon-free (Suzuki et al., 1992). High 'sy stem blanks', mainly associated with the amphoteric $\mathrm{Al}_{2} \mathrm{O}_{3}$ support (Benner and Storm, 1993; Cauwet, 1994), are a m ajor problem with HTCO techniques (Tanoue, 1992; Chen and Wange rsky, 1993; Sharp et al., 1993; Sharp et al. 1995). This seems to be the main reason for the large discrepancies among HTCO systems and with wet chemical oxidation techniques (Sugim ura and Suzuki, 1988; Martin and Fitzwater, 1992; Suzuki et al., 1992), as recognised in the cr iticism of the original papers (Suzuki 1993; Sharp et al. 1995). In addition to $\mathrm{Al}_{2} \mathrm{O}_{3}-\mathrm{CO}_{2}$ sorption-desorption effects, mechanical action can contribute to the HTCO-DOC 'sy stem blank' from a well-conditioned cataly st; the IRGA is affected by changes in flow through the measurement-cell, such as tho se associated with the expansion (three orders of magnitude increase in volume) of the liquid sam ples after injection onto the catalyst at $680^{\circ} \mathrm{C}$.

Although 'system blanks' change from catalyst to catalyst (generally from 5 to $12 \mu \mathrm{mol}$ $\mathrm{C}^{-1}$ and from $<0.3$ to $0.6 \mu \mathrm{mol} \mathrm{N} \mathrm{^{-1 }}$ in our records), they typically vary $\pm 2 \mu \mathrm{mol} \mathrm{C} \mathrm{^{-1 }}$ and \pm 0.2

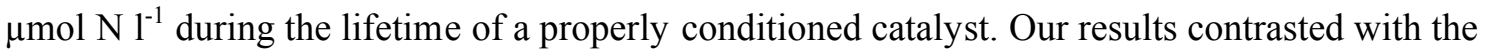
TDN 'system blanks' obtained by Koike and Tupas (1993) of $2.4 \pm 0.5 \mu \mathrm{mol} \mathrm{N} 1^{-1}$. To keep the background signal low, the carrier gas is passed through $\mathrm{CO}_{2}$ (hydropurge/mol. sieve 13X; Fisons, Loughborough, UK) and organics (activ ated Charcoal; Fisons, Loughborough, UK) scrubbers before entering the Shimadzu TOC-5000.

No significant differences have been found between slopes of calibration curves performed in Milli-Q and filtered natural sea wa ter for either DOC nor TDN (not shown). Consequently, calibration in Milli-Q is preferred for routine analysis because of its low organic carbon and nitrogen content and lower risk of biological degradation and contam ination (seawater must be previously filtered and decarbonated). No differences have been obtained for DOC when calibrating the sy stem with potassium hydrogen phthalate (KHP) or sodium bicarbonate $\left(\mathrm{NaHCO}_{3}\right)$, indicating com plete oxidation of the organic standard. In addition, $\mathrm{NaHCO}_{3}$ injected through the IC port (ie. bypassing the TC combustion column; Fig. 1a) yields 
the same calibration slope as injection through the TC

port. Consequently, no detectable adsorption or losses of com busted products occurs within the column or between the injection sites; in contrast to the large sorption-desorption effects observed by Cauwet (1994). Blanks from injection through the IC port only account for traces of IC in Milli-Q, whilst injection through the TC port produces a com bined value from DOC in Milli-Q and the 'sy stem blank' (Laodong and Santschi, 1997).

\subsection{Recovery experiments}

Recovery experiments with nitrogen compounds were performed, covering the whole range of oxidation states of naturally occurring nitrogen (from -3 to +5 ) and representing a variety of chemical structures. Quantitative recovery (96-103\%) relative to glycine (Table 1) has been obtained for all inorganic nitrogen salts tested $\left(\mathrm{NH}_{4} \mathrm{Cl}, \mathrm{NaNO}_{2}, \mathrm{KNO}_{3}\right)$ and some reference organic compounds (caffeine, EDTA, nicotinic acid, thiourea, urea), recalcitrant organic compounds (e.g. sulphathiazole), poorly oxidised by Suzuki et al. (1985), and biochemicals (arginine, histidine, thy midine). However, an tipyrine yielded a relatively low recovery of nitrogen (85\%), as observed by Cifuentes et al. (1994). Antipy rine has been shown to y ield about $30 \%$ by persulphate oxidation, $50 \%$ by UV oxidation and $94 \%$ by $\mathrm{HTO}$ at $1100{ }^{\circ} \mathrm{C}$ (Hopkinson et al., 1993). Addition of an on-line chromatography furnace at $1100{ }^{\circ} \mathrm{C}$ after the Tpiece (Fig. 1b) did not effect the recovery of antipyrine. Low recovery of antypirine could be due to formation of $\mathrm{NO}_{2}$ instead of $\mathrm{NO} \bullet$ and subsequent lost as $\mathrm{HNO}_{3}$, with condensation on the walls of the analyser tubing. $\mathrm{NO}_{2}$ arriving to the furnace should be decomposed to $\mathrm{NO} \bullet$ at 1100 ${ }^{\circ} \mathrm{C}$. Alternatively, production of $\mathrm{N}_{2}$ instead of $\mathrm{NO} \bullet$ in the com bustion tube (at $680{ }^{\circ} \mathrm{C}$ ) from DON compounds containing -N-N- bonds (e.g. antipyrine), may be a quantitatively significant reaction pathway. Since $\mathrm{N}_{2}$ is therm odynamically much more stable than $\mathrm{NO} \bullet$, the relative success of the $\mathrm{HTO} \mathrm{m}$ ethod at $1100{ }^{\circ} \mathrm{C}$ (Walsh, 1989) $\mathrm{m}$ ay be due to the predominance of kinetic over therm odynamic control on the oxidation of antipy rine at higher tem peratures. Accordingly, $-\mathrm{N}-\mathrm{N}-$ or $-\mathrm{N}=\mathrm{N}-$ com pounds, would not be recalcitrant (i.e. difficult to oxidise), but would be only semi-quantitatively decomposed to NO•. 


\subsection{Nature of bonded-N and peak shape}

It is important to note that strong dependence of peak shape on the nature of the nitrogen compound has been observed during the recovery experiments, even though peak areas are consistent. A conspicuous exam ple is shown in Figure 3, for the three inorganic nitrogen salts: ammonium (N-oxidation state, -3$)$, nitrite $(+3)$ and nitrate $(+5)$. Note that by contrast with ammonium-N, both nitrite- $\mathrm{N}$ and nitrate- $\mathrm{N}$ m ust be 'reduced' to $\mathrm{NO} \bullet$ (N-oxidation state, +2$)$, and that such a 'reduction' $m$ ust occur under oxidative conditions; i.e. decomposition to NO• must occur through different reaction mechanisms depending on the nature of the nitrogen compound.

Measuring peak height instead of peak area can obviously lead to significant errors. Using a glycine standard (N-oxidation state, -3), TDN would be underestim ated in deep-water samples, where nitrate is dom inant. On the cont rary, if a nitrate standard was used, DON in nitrate-free surface waters would be clearly overestimated. This was one of the reasons argued by Suzuki (1993) to explain the extrem ely high DON numbers in surface waters; even though a urea (oxidation state -3) standard had been used in the original paper (Suzuki et al. 1985).

Repeated injections of sea water pr ogressively improves peak shape as sea-salt gradually 'cements' the Shim adzu $\mathrm{Al}_{2} \mathrm{O}_{3}$ balls, thus reducing pressure surges caused by expansion of the sample upon injection. Peak shape im provement when adding $\mathrm{CuO}$ wire at the top of the catalyst (Sharp et al., 1993) may be due to the same mechanical effect, rather than any catalytic effect. Peak area is not affected by progressive improvement in peak shape.

\subsection{Shipboard analysis}

The analytical system was tested aboard ship, during cruise R.R.S. Challenger 123B, from 29 November to 15 December 1995. In spite of bad weather conditions over the Hebridean Shelf (West of Scotland, UK), shipboard HT CO-DOC and TDN analy ses were successfully performed immediately after sam ple collection. Precision of the $\mathrm{m}$ easurements was not compromised by the vibrations associated with the ship. The calibration procedure onboard was the same as in the base laboratory (see section 3.1). The CV for the slope of the 8 calibrations 
run was $1.5 \%$ for HTCO-DOC and $0.9 \%$ for HTCO-TDN. The sy stem blanks were 10

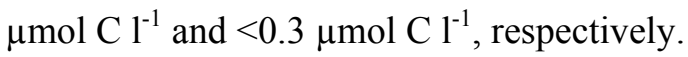

Samples were collected from 101 PVC Niskin bottles in $250 \mathrm{~m} 1$ all-glass flasks. They were immediately filtered through Whatm an GF/F filters (ashed $450{ }^{\circ} \mathrm{C}, 4$ hours), under positive pressure of high purity oxygen, in an all-glass filtration sy stem, and collected in $10 \mathrm{ml}$ glass ampoules (ashed $450{ }^{\circ} \mathrm{C}, 12$ hours). After acidification with $\mathrm{H} \quad{ }_{3} \mathrm{PO}_{4}$ to $\mathrm{pH}<2$, am poules were heat-sealed and preserved in the dark at $4{ }^{\circ} \mathrm{C}$, until analy sed on board. The CVs for the 4 replicate analyses of each sample were typically $<1.5 \%$ for both DOC and TDN m easurements. Examples of full water colum n profiles showing HTCO-DOC and TDN are illustrated in figure 4. A poleward-flowing surface $\mathrm{m}$ ixed layer (100m deep) has been found, both warm er and fresher than the waters below. HTCO-DOC and DON concentrations are quasi-homogeneously distributed through this layer and are clearly higher than in deeper waters.

\section{Conclusions}

Simultaneous, rapid, and highly precise sh ipboard measurements of HTCO-DOC and TDN can be routinely performed by coupling commercially available instruments. Comparison of a broad range of standard $\mathrm{m}$ aterials indicates quantitative recovery of oceanic dissolved organic matter (DOM). Most of the initial $\mathrm{m}$ ethodological problems associated with the application of HTCO technology to oceanogr aphic DOC analy sis have been resolved. Consequently, the technique is now being a pplied in studies of the biogeochemical and ecological dynamics of marine DOM. Parallel developm ent of the HTCO-DON methodology, leading to simultaneous determination of the DOM-C/N ratios will contribute significantly to these goals. 


\section{Acknowledgements}

The authors are very grateful to the captain and crew of R.R.S. Challenger for their help during cruise CH123B. We thank Prof. R.F.C. Ma ntoura for his support during this work. We may also express our gratitude to Drs R. Jones (F lorida International University, Miami), D.A. Hansell (Bermuda Biological Station for Research Inc.) and M. Anderson (National Environmental Laboratory, Hawaii) for their valuable advise during the early development of the method. Thanks to B. Grantham (Dunstaffnage Marine Laboratory, Scotland) for providing nutrient analysis. E.T. Peltzer and two anonymous reviewers provided valuable criticisms on the manuscript. Support for this work cam e from the EC MAST-II project OMEX (grant No MAS2-CT-93-0069), the UK DoE grant No PECD 7/8/233 and the NERC Special Topic GST/01/1355. A postdoctoral fellowship from the EC MAST-II programme (grant No. MAS2CT-94-5020) allowed X.A.A.-S. to carry out this work at the Plymouth Marine Laboratory. 
Benner, B. and Storm, M., 1993. A critical evaluation of the analy tical blank associated with DOC measurements by high-temperature catalytic oxidation. Mar. Chem., 1:153-160.

Cauwet, G., 1994. HTCO method for dissolved organic carbon analy sis in seawater: influence of catalyst on blank estimation. Mar. Chem., 47:55-64.

Cifuentes, L., López-Veneroni, D. and Coffin, R.B., 1994. Coupling the Shimadzu TOC-5000 with the NOx detection for TDN in seawater. E.O.S. 75 (A.G.U., Feb 94), 022Q-b.

Chen, W. and Wangersky, P.J., 1993. A high-temperature catalytic oxidation method for the determination of marine dissolved organic carbon and its comparison with the UV photooxidation method. Mar. Chem., 42:95-106.

Hansell, D.A., 1993. Results and observations from the m easurement of DOC and DON in seawater using a high-temperature catalytic oxidation technique. In: J.I. Hedges and C. Lee (Editors), Measurements of dissolved organic carbon and nitrogen in natural waters. Mar. Chem., 41:195-202.

Hansell, D.A., Williams, P.M. and Ward, B.B., 1993. Measurem ents of DOC and DON in the Southern California Bight using oxidation by high tem perature combustion. Deep-Sea Res., (I) 40:219-234.

Hedges, J.I. and Lee, C. (Editors), 1993. Measurem ents of dissolved organic carbon and nitrogen in natural waters. Proceedings NSF/NOAA/DOE Workshop, Seattle, WA, USA, 15-19 July 1991. Mar. Chem., 41(1-3).

Hedges, J.I., 1993. Com parative analyses of DOC and DON in natural waters. In: J.I. Hedges and C. Lee (Editors), Measurem ents of dissolved organic carbon and nitrogen in natural waters. Mar. Chem., 41:121-134.

Hopkinson, C., Cifuentes, L., Burdige, D., Fitzwater, S., Hansell, D., Henrichs, S., Kähler, P., Koike, Y., Walsh, T. and Bergam aschi, B., 1993. DON subgroup report. In: J.I. Hedges and C. Lee (Editors), Measurem ents of dissolved organic carbon and nitrogen in natural waters. Mar. Chem., 41:23-36

Koike, Y. and Tupas, L.; 1993. Total dissolved nitrogen in the Northern North Pacific assessed by a high-temperature combustion method. Mar. Chem., 41:209-214. 
Laodong, G. and Santschi, P.H., 1997. Measurement of dissolved organic carbon (DOC) in sea water by high temperature combustion method. Acta Oceanologica Sinica, 16:339-353.

Martin, J.H. and Fitzwater, S.E., 1992. Dissolved organic carbon in the Atlantic, Southern and Pacific oceans. Nature, 356:699-701.

Pelzter, E.T. and Brewer, P.G., 1993. Som e practical aspects of $m$ easuring DOC - sam pling artefacts and analy tical problems with $\mathrm{m}$ arine samples. In: J.I. Hedges and C. Lee (Editors), Measurements of dissolved organic carbon and nitrogen in natural waters. Mar. Chem., 41:23-252.

Perdue, E.M., Mantoura, F., Ertel, J., Lee, C., Mopper, K., Pey ton, G., Tanoue, E., Williams, P.M., Zafirou, O. and Coble, P., 1993. Mech anisms subgroup report. In: J.I. Hedges and C. Lee (Editors), Measurem ents of dissolved organic carbon and nitrogen in natural waters. Mar. Chem., 41:51-60.

Sharp, J.H., Benner, R., Bennett, L., Carlson, C.A. and Dow, R., 1993. Re-evaluation of high temperature combustion and chem ical oxidation m easurements of dissolved organic carbon in seawater. Limnol. Oceanogr., 38:177-1782.

Sharp, J.H., Benner, R., Bennett, L., Carlson, C. A., Fitzwater, S.E., Peltzer, E.T. and Tupas, L.M., 1995. Analyses of dissolved organic carbon in seawater: the JGOFS EqPac methods comparison. Mar. Chem., 48:91-108.

Sugimura, Y., Suzuki, Y., 1988. A high-tem perature catalytic oxidation method for the determination of non-volatile dissolved organic carbon in seawater by direct injection of a liquid sample. Mar. Chem., 24:105-131.

Suzuki, Y., 1993. On the $\mathrm{m}$ easurement of DOC and DON in seawater. In: J.I. Hedges and C. Lee (Editors), Measurements of dissolved organic carbon and nitrogen in natural waters. Mar. Chem., 41:287-288.

Suzuki, Y., Sugimura, Y., and Itoh, T., 1985. A Cataly tic oxidation $\mathrm{m}$ ethod for the determination of total nitrogen dissolved in seawater. Mar. Chem., 16:83-97. 
Suzuki, Y., Tanoue, E. and Ito, H., 1992. A high-temperature catalytic oxidation method for the determination of dissolved organic carbon in seawater: analy sis and improvement. DeepSea Res. I, 39:185-198.

Tanoue, E., 1992. Vertical distribution of dissolved organic carbon in the North Pacific as determined by the high-tem perature catalytic oxidation method. Earth Plan. Sci. Lett., 111:201-206.

Tanoue, E., 1993. Distributional characteristics of DOC in the Central Equatorial Pacific. J. Oceanogr., 9:625-639.

Walsh, T.W., 1989. Total dissolved nitrogen in seawater: a new high-temperature combustion method and a comparison with photo-oxidation. Mar. Chem., 26:295-311.

Williams, P.M., 1992. Measurement of dissolved organic carbon and nitrogen in natural waters. Oceanography, 5:107-116. 
Table 1. Results of the recovery experiments with N-containing materials. Percentages relative to glycine recovery (100\%). No of replicates, 3-5; C.V.(\%) $<2 \%$.

\begin{tabular}{lcc}
\hline Material & Spiked-N $(\mu \mathrm{M}-\mathrm{N})$ & Recovery (\%) \\
\hline ammonium chloride & +25.3 & $97 \%$ \\
antypirine & +24.6 & $85 \%$ \\
arginine & +25.4 & $102 \%$ \\
caffeine & +25.3 & $97 \%$ \\
EDTA & +24.8 & $102 \%$ \\
histidine & +26.7 & $102 \%$ \\
nicotinic acid & +24.5 & $101 \%$ \\
sodium nitrite & +24.7 & $101 \%$ \\
potassium nitrate & +24.8 & $102 \%$ \\
sulphathiazole & +24.3 & $99 \%$ \\
thiourea & +23.9 & $96 \%$ \\
thymidine & +25.7 & $103 \%$ \\
urea & +25.2 & $101 \%$ \\
\hline
\end{tabular}


Fig. 1. Analytical system for the simultaneous determination of DOC and TDN by HTCO. (a) Details of the Shimadzu TOC-5000 analyser and the LiCor Li6252 IRGA; (b) and details of the LiCor Li6252 IRGA and Antek 705D Nitrogen Detector.

Fig. 2. Peaks simultaneously obtained with: (a) the LiCor Li6252 IRGA and (b) the Antek 705D Nitrogen Detector, in conjunction with the in tegration software package ATI Unicam 4880. (c) Collection of calibration curves for HTCO-DOC and TDN, obtained with the same combustion column during routine analy sis in the laboratory . m, slope; a, intercept; $r^{2}$, correlation coefficient for the com posite calibration curve. Sy stem blank for the colum n: 6

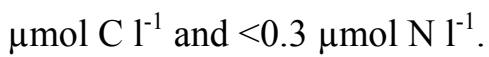

Fig 3. Com parative peak shape for $\mathrm{NH}_{4} \mathrm{Cl}, \mathrm{NaNO}_{2}$, and $\mathrm{KNO}_{3}$ spiked in Milli-Q ${ }^{\circledR}$ water. Concentration is $\sim 25 \mu \mathrm{mol} \mathrm{N}{ }^{-1}$ for the three inorganic nitrogen salts.

Fig. 4. Full water column profiles of (a) HTCO-DOC and (b) HTCO-TDN, for station S1500 (1500m deep), in the Hebridean Shelf (West of Scotland, UK). Average CVs $1.2 \%( \pm 0.8$

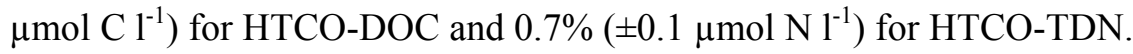


Shimadzu TOC-5000

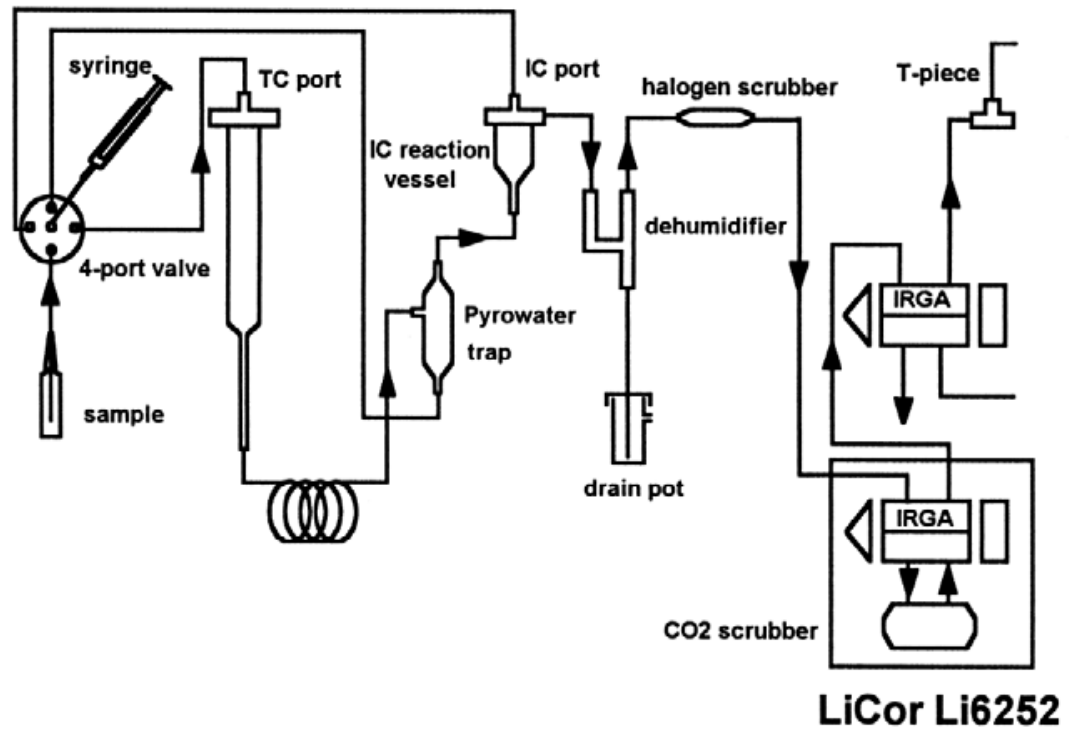

(a)

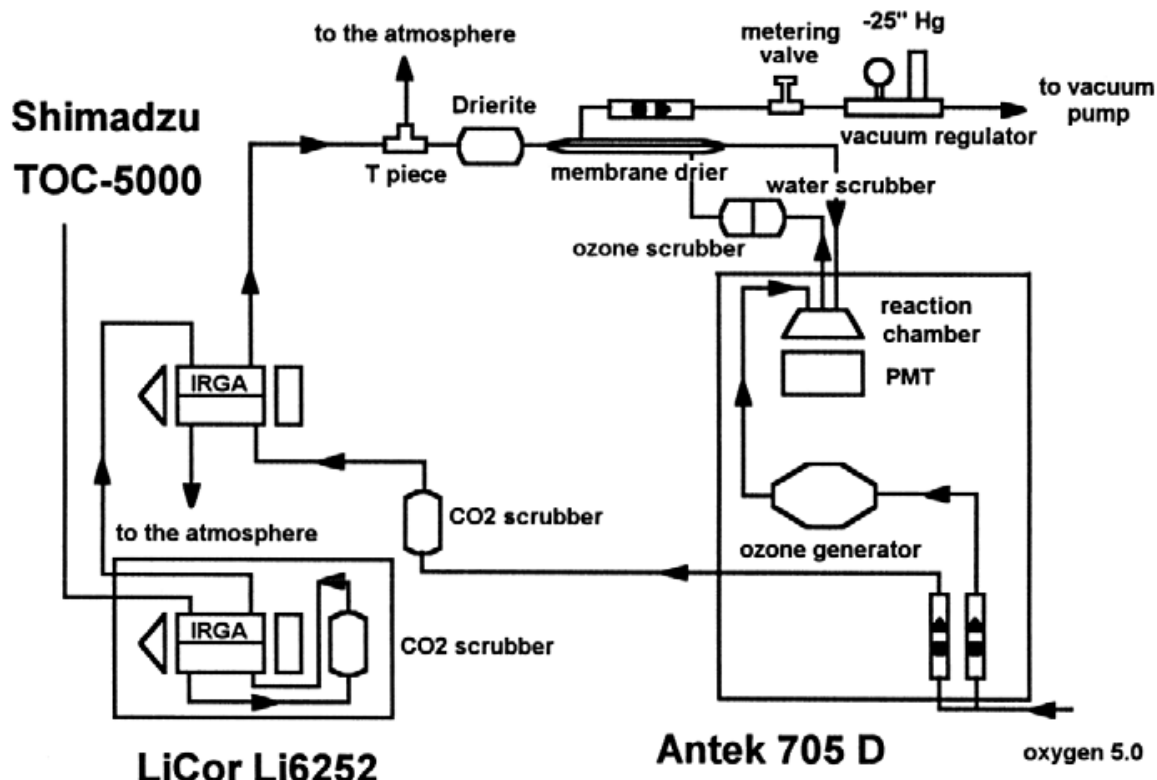

(b)

Figure 1 

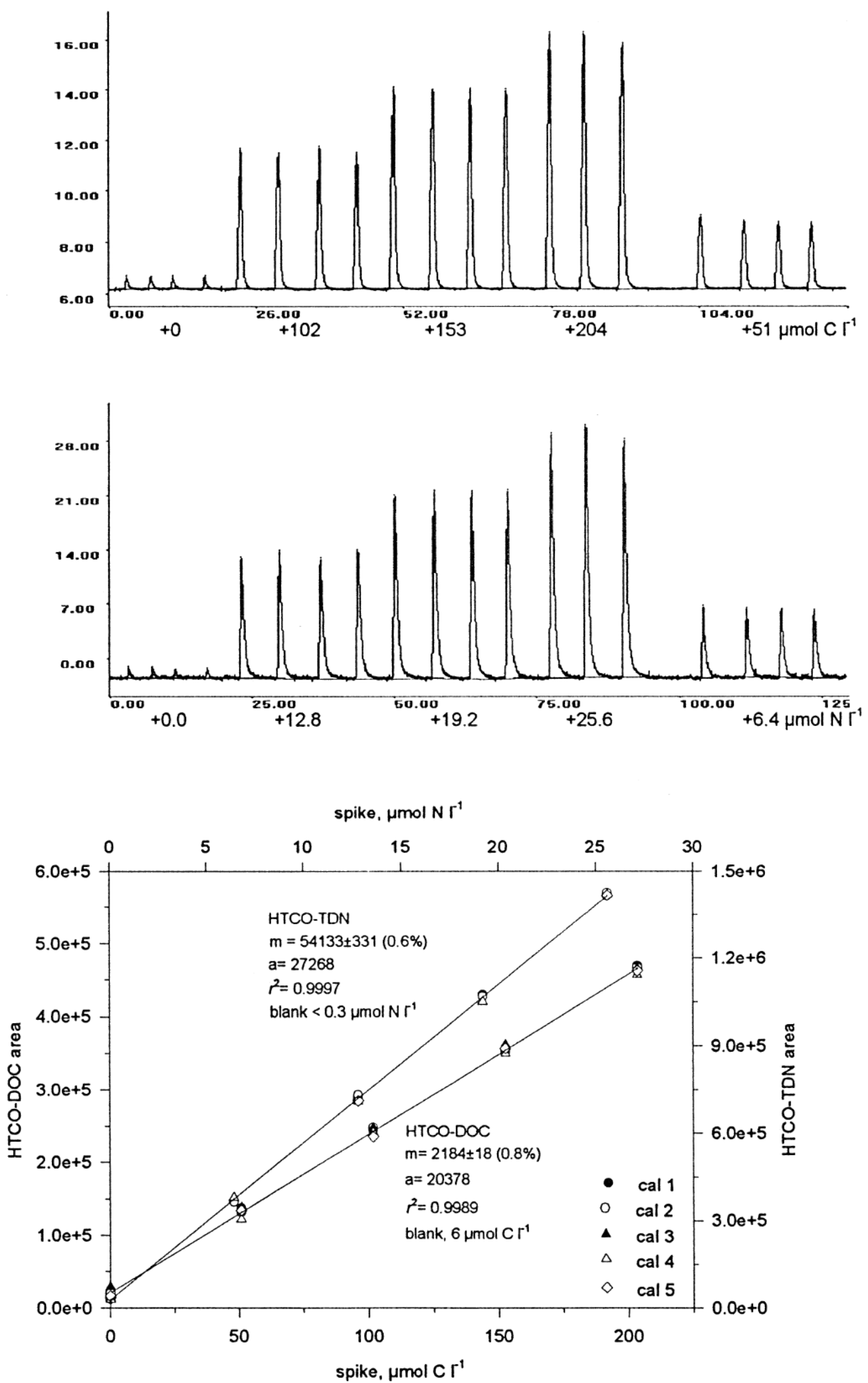

(c)

Figure 2 


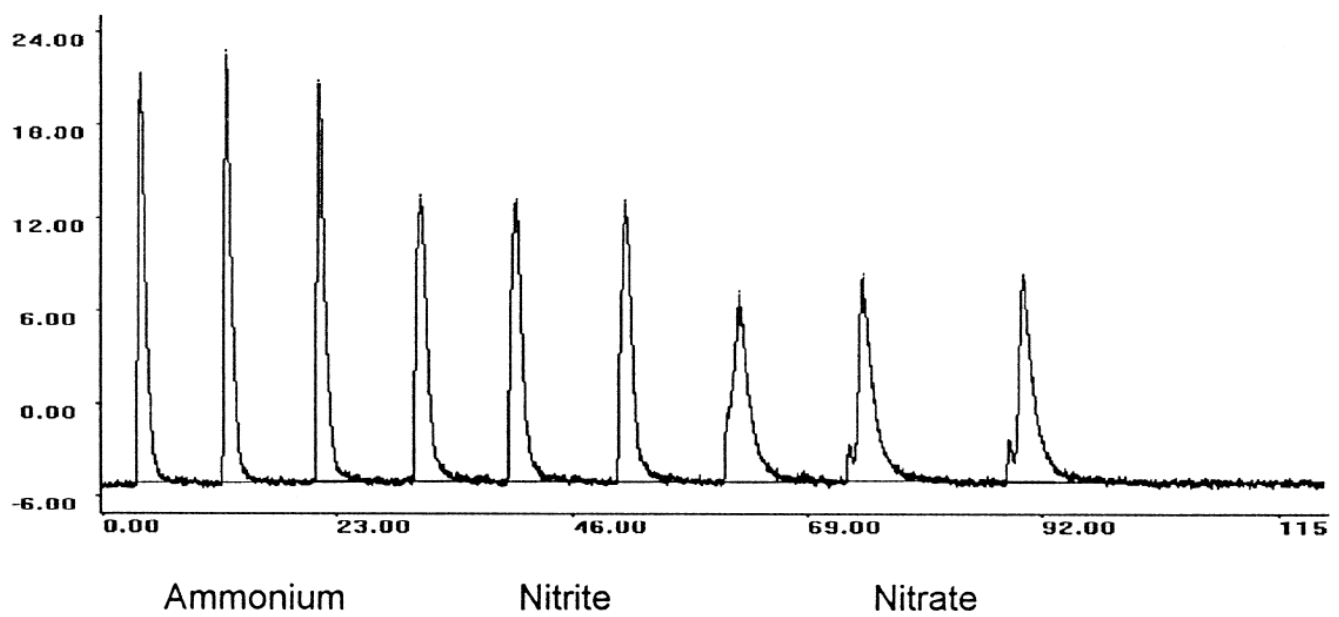

Figure 3 

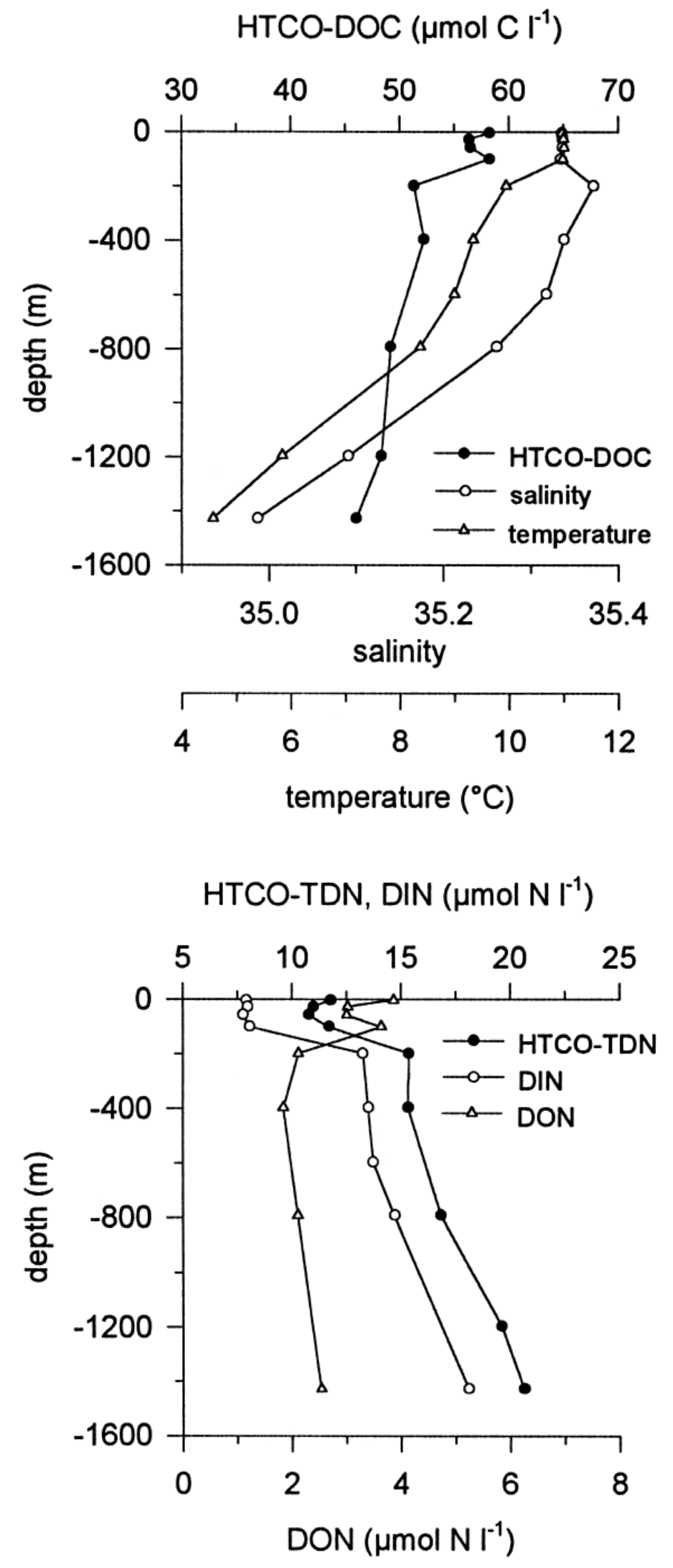

Figure 4 